\title{
Breakthrough SARS-CoV-2 infections in MS patients on disease modifying therapies
}

2 Irene Schiavetti ${ }^{1}$, Cinzia Cordioli ${ }^{2}$, Maria Laura Stromillo ${ }^{3}$, Maria Teresa Ferrò ${ }^{4}$, Alice Laroni ${ }^{5,6}$, Eleonora

$3 \mathrm{Cocco}^{7}$, Gaia Cola ${ }^{8}$, Livia Pasquali ${ }^{9}$, Maria Teresa Rilla ${ }^{10}$, Elisabetta Signoriello ${ }^{11}$, Rosa Iodice ${ }^{12}$, Alessia Di

4 Sapio $^{13}$, Roberta Lanzillo ${ }^{14}$, Francesca Caleri ${ }^{15}$, Pietro Annovazzi ${ }^{16}$, Antonella Conte ${ }^{17,18}$, Giuseppe

5 Liberatore $^{19}$, Francesca Ruscica ${ }^{20}$, Renato Docimo ${ }^{21}$, Simona Bonavita ${ }^{22}$ Monica Ulivelli $^{23}$, Paola Cavalla ${ }^{24}$,

6 Francesco Patti ${ }^{25}$, Diana Ferraro ${ }^{26}$, Marinella Clerico ${ }^{27}$, Paolo Immovilli ${ }^{28}$, Massimiliano Di Filippo ${ }^{29}$, Marco

$7 \quad$ Salvetti $^{30,18}$, Maria Pia Sormani ${ }^{1,5}$ and the "Breakthrough infections in MS" study group

8

9

1. Department of Health Sciences, Section of Biostatistics, University of Genova, Italy

2. Centro Sclerosi Multipla ASST Spedali Civili di Brescia

3. Clinica Neurologica e Malattie Neurometaboliche, Università degli Studi di Siena

4. Neuroimmunology, Center for Multiple Sclerosis, Cardiocerebrovascular Department, Neurological Unit, ASST Crema

5. IRCCS Ospedale Policlinico San Martino, Genova, Italy

6. Department of Neurosciences, Rehabilitation, Ophthalmology, Genetics, Maternal and Child Health, University of Genova, Italy

7. Centro Sclerosi Multipla Ospedale Binaghi Cagliari

8. "Department of Systems Medicine, Multiple Sclerosis Clinical and Research Unit, Tor Vergata, University, Rome, Italy"

9. Department of Clinical and Experimental Medicine, Neurology Unit, University of Pisa, Italy

10. Department of Neurology, Imperia Hospital, Imperia, Italy

11. II Division of Neurology, University of Campania Luigi Vanvitelli

12. Department of Neurosciences, Reproductive Sciences and Odontostomatology, University of Naples "Federico II", Naples, Italy

13. Department of Neurology, Regina Montis Regalis Hospital, Mondovì, Italy

14. Federico II University of Naples

15. Department of Neurology, MS Center, F. Tappeiner Hospital Meran (BZ), Italy

16. UOC Centro Sclerosi Multipla, ASST Valle-Olona, PO di Gallarate (VA)

17. Department of Human Neuroscience, Sapienza, University of Rome, Italy.

18. IRCCS Neuromed, Pozzilli (IS), Italy

19. Neuromuscular and Neuroimmunology Unit, IRCCS Humanitas Research Hospital, Rozzano, Italy

20. U.O.C. Neurologia e Centro SM - Fondazione Istituto G. Giglio, Cefalù (Italy)

21. Multiple Sclerosis Center, Aversa Hospital "San Giuseppe Moscati", ASL Caserta, Aversa (Ce) Italy

22. Dipartimento di Scienze Mediche e Chirurgiche avanzate, Università della Campania Luigi Vanvitelli, NaplesItaly

23. Department of Medical Sciences, Surgery and Neurosciences, University of Siena

24. Multiple Sclerosis Center and 1st Division of Neurology, Department of Neuroscience, City of Health and Science University Hospital of Turin, Italy 
25. Department of Medical and Surgical Sciences and Advanced Technologies, GF Ingrassia, University of Catania, Catania, Italy.

26. Department of Biomedical, Metabolic and Neurosciences, University of Modena and Reggio Emilia, Modena, Italy.

27. Clinical and Biological Sciences Department, University of Torino

28. Guglielmo da Saliceto Hospital, Piacenza

29. Department of Medicine and Surgery, Section of Neurology, University of Perugia, Perugia, Italy

30. Department of Neuroscience, Mental Health and Sensory Organs, Sapienza University of Rome, Rome, Italy

Corresponding author: Maria Pia Sormani, Department of Health Sciences, Via Pastore 1, 16132,

University of Genova, Italy

Email: mariapia.sormani@unige.it

Tel: +39-3669937472

Keywords: Multiple Sclerosis, Covid-19 vaccination, Breakthrough infections

Number of characters in the title: 80

Number of words: 1394

Number of figures: 1

Number of tables: 1

Number of references: 11 
medRxiv preprint doi: https://doi.org/10.1101/2022.01.22.22269630; this version posted January 31, 2022. The copyright holder for this preprint

(which was not certified by peer review) is the author/funder, who has granted medRxiv a license to display the preprint in perpetuity.

All rights reserved. No reuse allowed without permission.

60

61

62

63

64

65

66

67

68

69

70

71

72

73

74

75

76

77

\section{Abstract}

Background. Patients with Multiple Sclerosis (pwMS) treated with anti-CD20 or fingolimod showed a reduced humoral response to SARS-CoV-2 vaccines. In this study we aimed to monitor the risk of breakthrough SARS-CoV-2 infection in pwMS on different Disease Modifying Therapy (DMT).

Methods. Data on number of vaccinated patients and of patients with a breakthrough infection were retrospectively collected in 27 Italian MS centers. We estimated the rate of breakthrough infections and of infection requiring hospitalization per DMT.

Findings. 19641 vaccinated pwMS were included in the database. After a median follow-up of 8 months, we observed 137 breakthrough infections. As compared to the other DMTs, the rate of breakthrough infections was significantly higher on ocrelizumab $(0.57 \%$ vs $2.00 \%, \mathrm{RR}=3.55,95 \% \mathrm{CI}=2.74-4.58, \mathrm{p}<0.001)$ and fingolimod $(0.58 \%$ vs $1.62 \%, \mathrm{RR}=2.65,95 \% \mathrm{CI}=1.75-4.00, \mathrm{p}<0.001)$, while there were no significant differences in any other DMT group. In the ocrelizumab group the hospitalization rate was $16.7 \%$ vs $19.4 \%$ in the pre-vaccination era $(\mathrm{RR}=0.86, \mathrm{p}=0.74)$ and it was $3.9 \%$ in all the other DMT groups vs $11.9 \%$ in the pre-vaccination period $(\mathrm{RR}=0.33, \mathrm{p}=0.02)$.

Interpretation. The risk of breakthrough SARS-CoV-2 infections is higher in patients treated with ocrelizumab and fingolimod, and the rate of severe infections was significantly reduced in all the DMTs excluding ocrelizumab. 


\section{Introduction}

Several recent studies evaluated the effect of vaccination against SARS-CoV-2 in patients with multiple sclerosis (pwMS) treated with disease-modifying therapies (DMTs). There is wide consensus that the use of anti-CD20 monoclonal antibodies and fingolimod are associated with an impaired virus-specific humoral immune response as compared to all the other $\mathrm{DMTs}^{1-4}$. On the other hand, there is also growing evidence that vaccinated pwMS treated with anti-CD20 generated robust virus specific CD4 and CD8 T cell responses $^{4-5}$, while these are slightly reduced in fingolimod treated patients ${ }^{5}$. A preliminary follow-up study of 344 fully vaccinated pwMS on DMT reported 13 breakthrough infections, 10 of which were in patients on anti-CD20 therapy and the remaining 3 on fingolimod ${ }^{6}$, suggesting a relevant role of antibodies in preventing the infection. The French registry recently reported a case series of 18 pwMS who had Covid-19 after two doses of BNT162b2-vaccination, 13 of which treated with anti-CD20 and four with fingolimod ${ }^{7}$. Finally, the clinical follow up of the CovXiMS study ${ }^{1}$ evaluating humoral response in 1705 pwMS who received two doses of mRNA vaccines ${ }^{8}$, reported 23 breakthrough infections over a 6 month follow up. The risk of infection was associated with lower SARS-CoV-2 antibody levels measured after 4 weeks from the second vaccine dose $e^{8}$.

Against this background and taking advantage of the large network of MS centers within the Italian Alliance against Covid-19 promoted by the Italian MS Society, we collected data from 27 Italian MS centers on the number of vaccinated patients and the number of patients who had a breakthrough infection in each DMT group, in the period preceding the spread of the Omicron variant, that started its massive diffusion in Italy after the December 2021 holiday season. Aim of this study is to estimate the rate of breakthrough infections per DMT class on a large sample of vaccinated pwMS and to compare the rates of severe infections to the rate observed in Italy in the pre-vaccination era ${ }^{9}$.

\section{Patients and Methods}



group from March 2021 to December 25, 2021. Data cutoff was set before the spread of the Omicron variant in Italy, since on December 23, 2021 the percentage of Omicron infections was estimated to be $28 \%$ (https://www.iss.it/primo-piano, accessed on December 25, 2021). Breakthrough infections occurred within 8 months, defined as a PCR-confirmed test after 14 days from the second or the third vaccine dose, were extracted from the platform dedicated to Covid-19 data collection in pwMS (MuSC-19 database ${ }^{10}$ ) for the Form (CRF).

The study is done in compliance with the principles of the Declaration of Helsinki. The study was approved by the regional ethics committee of Liguria (University of Genoa; n 130/2020-DB id 10433) and at a national level by the Italian Medicines Agency. Written informed consent was obtained from all participants before starting any study procedures.

The primary objective of this analysis was to compare the incidence of breakthrough SARS-CoV-2 infections among the vaccinated pwMS in each DMT group. These conditions entail a PCR-confirmed swab, and a time lag of at least 14 days from a full vaccination cycle (after the second or third vaccination dose, or after the first dose following a Covid-19 infection).

\section{Statistical analysis}

123 The percentage of patients with a breakthrough infection in the different DMT groups was calculated. 95\%

124 Confidence Intervals (CI) were estimated using the normal approximation to the binomial calculation ${ }^{11}$.

125 Difference of rate of infections between DMT groups were estimated by Risk Ratios (RR) and evaluated by

126 Chi-square tests. Difference of rate of infections in the first 4 months vs the second 4 months of follow up

127 were estimated by ORs and evaluated by the McNamar test for paired data. 


\section{Results}

132

133

134

Data were collected between March 1, 2021 and December 24, 2021. 19641 pwMS who had a full vaccination cycle with an mRNA vaccine ( 2 or 3 vaccine dose, or 1 vaccine dose after Covid-19 infection) were included in the database. The number of vaccinated pwMS in each DMT group is reported in Table 1. The mean follow-up time was 249 days (range 99-354). Among them, 137 breakthrough infections were observed (26 (19.0\%) after the third dose, 1 after Covid-19 infection and one dose) over a mean interval after the last vaccine dose of 142 days (range 14-262) (Table 1). Over the whole follow-up of about 8 months, we compared the proportion of patients with breakthrough infections in each DMT group to the pooled proportion of the patients on all the other DMTs (Figure 1, panel A). The rate of breakthrough infections was significantly higher in patients treated with ocrelizumab $(2.00 \%, 95 \% \mathrm{CI}=1.36-2.66)$ than in patients treated with all the other DMTs $(0.57 \%, 95 \% \mathrm{CI}=0.46 \%-0.68 \%)$ with a $\mathrm{RR}=3.55,95 \% \mathrm{CI}=2.74-4.58$, $\mathrm{p}<0.001$; the same was observed in patients treated with fingolimod who had a higher rate of breakthrough infections $(1.62 \%, 95 \% \mathrm{CI}=1.02 \%-2.21 \%)$ than the patients treated with all the other DMTs $(0.61 \%$, $95 \% \mathrm{CI}=0.50-0.72$ ) with a $\mathrm{RR}=2.65,95 \% \mathrm{CI}=1.75-4.00, \mathrm{p}<0.001$. Among the patients who had the SARSCoV-2 infection, $10(7.3 \%)$ had a severe disease course and were hospitalized. Six patients treated with ocrelizumab were hospitalized and in this group the rate of hospitalization was $16.7 \%$, slightly lower but not significantly different than the pre-vaccination rate observed in Italy $(19.4 \%)$ in the same DMT group ${ }^{7}$ (relative reduction $=14 \%, \mathrm{RR}=0.86,95 \% \mathrm{CI}=0.38-1.91, \mathrm{p}=0.74)$. In the fingolimod group we observed just 1 hospitalized patient (3.6\%). The rate of hospitalization was 3.9\% in all the other DMT groups as compared to $11.9 \%$ in the pre-vaccination period $^{7}$ (relative reduction $=67 \%, \mathrm{RR}=0.33,95 \% \mathrm{CI}=0.13-0.88, \mathrm{p}=0.02$ ). One patient in ocrelizumab was admitted to the Intensive Care Unit (ICU) and recovered.

Figure1, panel B, reports the rate of breakthrough infections in two time periods of equal duration: the first 4 months following the last vaccination dose vs the period 4-8 months after the last vaccination dose in patients treated with ocrelizumab, fingolimod and all the other DMTs. The rate in patients treated with 
ocrelizumab and fingolimod was not significantly affected by the time since vaccination (ocrelizumab: 0-4 months after vaccination: $0.84 \%, 4-8$ months after vaccination: $1.18 \%, \mathrm{OR}=1.40, \mathrm{p}=0.31$; fingolimod: $0-4$ months after vaccination: $0.86 \%, 4-8$ months after vaccination: $0.76 \%, \mathrm{OR}=0.88, \mathrm{p}=0.75)$. In all the other DMT groups the rate is much lower (0-4 months after vaccination: $0.14 \%)$ and it was significantly increased after 4 months from the last vaccine dose (4-8 months after vaccination: $0.32 \%, \mathrm{OR}=2.32,95 \% \mathrm{CI}=1.38$ 4.01, $\mathrm{p}<0.001)$.

\section{Discussion}

This study on a large sample of pwMS who received a full vaccination cycle confirms that the risk of contracting SARS-CoV-2 infection after Covid-19 m-RNA vaccines is higher in pwMS on anti-CD20 monoclonal antibodies or fingolimod. We observed just one admission to ICU and no deaths. Despite the small sample of 137 infections, two results emerge. First, in our cohort, among the infected patients after vaccination treated with ocrelizumab the hospitalization rate is very similar to the hospitalization rate of patients on the same treatment in the pre-vaccination era $^{8}$, while it is reduced by $67 \%$ in pwMS in other DMTs. However, we must consider that this result can be confounded by an increased propensity of clinician to admit to hospital pwMS on ocrelizumab who develop Covid-19, because of previous studies showing that these patients are at a higher risk for a severe course ${ }^{8}$. Second, as expected ${ }^{9}$, the vaccine-induced protection from the disease is waning with time since vaccination, and this is more evident in patients treated with DMTs other than ocrelizumab and fingolimod, who already had low antibody levels soon after the vaccination. In fact, while the infection rate is similar in the first and in the second four months after vaccination in patients on ocrelizumab and fingolimod, and consistently higher than in patients on other DMTs, the initial protective effect is vanishing with time for patients in the other DMTs group, who had a good level of antibody response four weeks after vaccination ${ }^{1}$. This study complements the information of previous studies reporting the antibody levels after anti-SARS-Cov-2 vaccination in pwMS on different DMTs $^{1-7}$, suggesting that antibodies play a dominant role in preventing Covid-19 infections and their severe consequences. 
medRxiv preprint doi: https://doi.org/10.1101/2022.01.22.22269630; this version posted January 31, 2022. The copyright holder for this preprint (which was not certified by peer review) is the author/funder, who has granted medRxiv a license to display the preprint in perpetuity.

All rights reserved. No reuse allowed without permission.

\section{References}

1. Sormani MP, Inglese M, Schiavetti I et al. Effect of SARS-CoV-2 mRNA vaccination in MS patients treated with disease modifying therapies. EBioMedicine. 2021 Oct;72:103581. doi: 10.1016/j.ebiom.2021.103581.

2. Achiron A, Mandel M, Dreyer-Alster S, et al. Humoral immune response to COVID-19 mRNA vaccine in patients with multiple sclerosis treated with high-efficacy disease-modifying therapies. Ther Adv Neurol Disord. 2021. doi:10.1177/17562864211012835

3. Tallantyre EC, Vickaryous N, Anderson V et al. COVID-19 Vaccine Response in People with Multiple Sclerosis. Ann Neurol 2021; Oct 22. doi: 10.1002/ana.26251. Online ahead of print

4. Tortorella C, Aiello A, Gasperini C et al. Humoral- and T-Cell-Specific Immune Responses to SARS-CoV-2 mRNA Vaccination in Patients With MS Using Different Disease-Modifying Therapies. Neurology in press

5. Apostolidis SA, Kakara M, Painter MM, et al. Cellular and humoral immune responses following SARS-CoV-2 mRNA vaccination in patients with multiple sclerosis on anti-CD20 therapy. Nat Med. 2021 Nov;27(11):1990-2001. doi: 10.1038/s41591-021-01507-2.

6. Rose DR, Mahadeem AZ, Carlson AK et al. Clinical features and outcomes of COVID-19 despite SARS-CoV-2 vaccination in people with multiple sclerosis. Mult Scler J Exp Transl Clin. 2021 Nov 26;7(4):20552173211057110. doi: 10.1177/20552173211057110. eCollection 2021 Oct.

7. Januel E, De Seze J, Vermersch P et al. Post-vaccine COVID-19 in patients with multiple sclerosis or neuromyelitis optica. Mult Scler J. 2022; doi: 10.1177/ 13524585211049737.

8. Sormani MP, Schiavetti I, Carmisciano L et al. COVID-19 Severity in Multiple Sclerosis: Putting Data Into Context. Neurol Neuroimmunol Neuroinflamm. 2021 Nov 9;9(1):e1105. doi: 10.1212/NXI.0000000000001105. Print 2022 Jan.

9. Sormani MP, Schiavetti I, Inglese M et al. Breakthrough SARS-CoV-2 infections after COVID-19 mRNA vaccination in MS patients on disease modifying therapies. . medRxiv 2021.12.23.21268177; doi: https://doi.org/10.1101/2021.12.23.21268177. 
10. Sormani MP, De Rossi N, Schiavetti I, et al. Disease-Modifying Therapies and Coronavirus Disease 2019 Severity in Multiple Sclerosis. Ann Neurol. 2021;89(4):780-789. Doi:10.1002/ana.26028 Proportion". Statistical Science. 16 (2): 101-133.

\section{Acknowledgements}

\section{Disclosures}

Annovazzi received honoraria for lecturing and participation in advisory boards, and/or travel expenses for attending congresses and meetings from Almirall, Biogen, BMS-Celgene, Merck, Novartis, Roche, SanofiGenzyme, Teva Italia, and Viatris.

Bonavita received speaker and/or advisors board fee from Biogen, Novartis, Roche, viatris, Merck serono.

Caleri received honoraria for advisory board and/or for public speaking, and/or travel grant, from Biogen, Merck, Teva, Novartis, Sanofi-Genzyme, Roche.

Cavalla has received advisory board membership, speaker honoraria or travel grants to attend national and international conferences from Biogen, Merck-Serono, Teva, Roche, Novartis, Cellgene-BMS and SanofiGenzyme.

Clerico received grants and consulting fees from Merck, Biogen, Novartis, Sanofi-Genzyme, Roche, Almirall.

Cola, Pasquali, Cocco, Ferrò, Liberatore, Rilla, Stromillo have nothing to disclose.

Conte reports speaking honoraria from Merck, Sanofi, Novartis, Biogen, Roche, Bristol Myers Squibb,

Cordioli received personal compensation for advisory board and speaking for Merck Serono, Novartis, Almirall, Biogen and Roche.

Di Filippo participated on advisory boards for and received research support, speaker/writing honoraria and funding for traveling from Bayer, Biogen Idec, Genzyme, Merck, Mylan, Novartis, Roche, Teva and Viatris

Di Sapio received personal compensation for speaking and consulting by Biogen, Novartis and Genzyme and has been reimbursed by Merck, Biogen, Genzyme and Roche for attending several conferences.

Docimo received grants from Roche, Novartis, Biogen, Merck, Viatris, Genzyme.

Ferraro received travel grants and/or speaker/advisory board honoraria from Biogen, Roche, Novartis, TEVA, Sanofi Genzyme, Merck Serono. Roche. 
243 Lanzillo received personal compensations for speaking or consultancy from Biogen, Teva, Genzyme, Merck, 244 Mylan, Novartis and Roche.

245 Laroni received personal compensations from Merck, Biogen, Novartis, Roche, Almirall.

246 Patti received personal compensation for serving on advisory board Almirall, Bayer, Biogen, Bristol Meyers

247 Squibb, Merck, Novartis, Roche and Sanofi; he further received unrestricted research grants by Biogen,

248 Merck, Roche, FISM, University of Catania and Reload (onlus patients association).

249 Ruscica received speaker and/or advisors board fee from Merck, Novartis, Biogen, Genzyme.

250 Salvetti reports grants and personal fees from Biogen, Merck, Novartis, Roche, Sanofi, Teva, grants from 251 Italian Multiple Sclerosis Foundation, grants from Sapienza University of Rome.

252 Schiavetti received consulting fees from Hippocrates Research, NovaNeuro, Sakura Italia, ADL

253 Farmaceutici, Associazione Commissione Difesa Vista Onlus.

254 Signoriello received speaker honoraria and/or consultancy from Biogen, Teva, Genzyme, Merck, Novartis, 255 Almirall, Roche.

256 Sormani received consulting fees from Merck, Biogen, Novartis, Sanofi, Roche, Geneuro, GSK, Medday, 257 Immunic.

258 Ulivelli received consulting fees from Biogen, Novartis, Serono. 
medRxiv preprint doi: https://doi.org/10.1101/2022.01.22.22269630; this version posted January 31, 2022. The copyright holder for this preprint (which was not certified by peer review) is the author/funder, who has granted medRxiv a license to display the preprint in perpetuity.

All rights reserved. No reuse allowed without permission.

Table 1: Characteristics of patients with breakthrough infections $(\mathbf{N}=137)$

\begin{tabular}{|c|c|c|}
\hline \multicolumn{2}{|l|}{ Female sex } & $85(62.0)$ \\
\hline \multicolumn{2}{|l|}{ Age, years } & $42.3 \pm 10.70$ \\
\hline \multicolumn{2}{|l|}{ BMI (kg/m2) } & $24.6 \pm 4.95$ \\
\hline \multirow[t]{4}{*}{ MS phenotype } & Primary progressive & $9(6.6)$ \\
\hline & Relapsing remitting & $116(84.7)$ \\
\hline & Secondary progressive & $7(5.1)$ \\
\hline & Missing data & $5(3.6)$ \\
\hline \multicolumn{2}{|c|}{ Disease duration, months } & $99.5(44.0-182.0)$ \\
\hline \multicolumn{2}{|c|}{ Last EDSS before Covid-19 infection } & $2.0(1.0-3.5)$ \\
\hline \multicolumn{2}{|c|}{ Relapse in the six months before Covid-19 infection } & $7(5.1)$ \\
\hline \multirow{13}{*}{$\begin{array}{l}\text { Number of breakthrough } \\
\text { infections in each } \\
\text { DMT/number of } \\
\text { vaccinated patients, }(\%)\end{array}$} & alemtuzumab & $0 / 371(0.0)$ \\
\hline & azathioprine & 0/298 (0.0) \\
\hline & cladribine & $4 / 570(0.70)$ \\
\hline & dimethyl fumarate & $22 / 2668(0.82)$ \\
\hline & fingolimod & $28 / 1733(1.61)$ \\
\hline & glatiramer acetate & $4 / 1514(0.26)$ \\
\hline & interferon & $7 / 2452(0.29)$ \\
\hline & natalizumab & $15 / 1843(0.81)$ \\
\hline & ocrelizumab & $36 / 1794(2.00)$ \\
\hline & rituximab & $3 / 364(0.82)$ \\
\hline & teriflunomide & $10 / 1379(0.73)$ \\
\hline & other & $0 / 389(0.0)$ \\
\hline & untreated & $8 / 4266(0.19)$ \\
\hline \multicolumn{2}{|c|}{ Boost COVID-19 vaccination } & $26(19.0)$ \\
\hline \multicolumn{2}{|l|}{ Heterologous vaccine } & $4(2.9)$ \\
\hline \multirow[t]{6}{*}{ Covid severity } & Asymptomatic, viral RNA detected & $16(11.8)$ \\
\hline & Symptomatic, independent & $95(69.3)$ \\
\hline & Symptomatic, assistance needed & $16(11.8)$ \\
\hline & Hospitalized, no oxygen therapy & $4(2.9)$ \\
\hline & Oxygen by mask or nasal prongs & $5(3.7)$ \\
\hline & $\begin{array}{l}\text { Intubation and mechanical ventilation, } \\
\mathrm{piO} 2 / \mathrm{FiO} 2 \geq 150 \text { or } \mathrm{SpO} 2 / \mathrm{FiO} 2 \geq 200\end{array}$ & $1(0.7)$ \\
\hline
\end{tabular}

Results are expressed as count (\%), mean \pm Standard Deviation, or median [Inter Quartile Range], as appropriate.

$M S=$ Multiple Sclerosis, BMI=Body Mass Index, EDSS=Expanded Disability Status Scale, DMT=Disease Modifying Therapy 
medRxiv preprint doi: https://doi.org/10.1101/2022.01.22.22269630; this version posted January 31, 2022. The copyright holder for this preprint (which was not certified by peer review) is the author/funder, who has granted medRxiv a license to display the preprint in perpetuity.

All rights reserved. No reuse allowed without permission.

Breakthrough infections in MS study group

\begin{tabular}{|c|c|}
\hline Name Surname & Affiliation \\
\hline Agostino Giulio Lanuto & Federico II university of Naples \\
\hline Alessandro Giannotta & Department of Medical Sciences, Surgery and Neurosciences, University of Siena \\
\hline Alessia Di Sapio & Department of Neurology, Regina Montis Regalis Hospital, Mondovì, Italy \\
\hline Alice Laroni & $\begin{array}{l}1 \text { - Department of Neurosciences, Rehabilitation, Ophthalmology, Genetics, Maternal } \\
\text { and Child Health, University of Genova, Italy AND IRCCS Ospedale Policlinico San } \\
\text { Martino, Genova, Italy } \\
2 \text { - IRCCS Ospedale Policlinico San Martino, Genova, Italy }\end{array}$ \\
\hline Anastasia Alteno & $\begin{array}{l}\text { Multiple Sclerosis Center, Department of Neuroscience, City of Health and Science } \\
\text { University Hospital of Turin, Italy }\end{array}$ \\
\hline Antonella Conte & $\begin{array}{l}\text { 1- Department of Human Neuroscience, Sapienza, University of Rome, Italy. } \\
\text { 2- IRCCS Neuromed, Pozzilli (IS), Italy }\end{array}$ \\
\hline Carlo Serrati & Ospedale Civile Imperia \\
\hline Caterina Lapucci & IRCCS Ospedale Policlinico San Martino, Genova, Italy \\
\hline Chiara Rosa Mancinelli & Centro Sclerosi Multipla ASST Spedali Civili di Brescia \\
\hline Cinzia Cordioli & Centro Sclerosi Multipla ASST Spedali Civili di Brescia \\
\hline Clara Grazia Chisari & $\begin{array}{l}\text { Department of Medical and Surgical Sciences and Advanced Technologies, GF } \\
\text { Ingrassia, University of Catania, Catania, Italy. }\end{array}$ \\
\hline Daiana Bezzini & Department of Life Sciences, University of Siena \\
\hline Damiano Baroncini & UOC Centro Sclerosi Multipla, ASST Valle-Olona, PO di Gallarate (VA) \\
\hline Diana Ferraro & $\begin{array}{l}\text { Department of Biomedical, Metabolic and Neurosciences, University of Modena and } \\
\text { Reggio Emilia, Modena, Italy }\end{array}$ \\
\hline Donata Guidetti & Guglielmo da Saliceto Hospital, Piacenza \\
\hline Doriana Landi & $\begin{array}{l}\text { Department of Systems Medicine, Multiple Sclerosis Clinical and Research Unit, Tor } \\
\text { Vergata } \\
\text { University, Rome, Italy }\end{array}$ \\
\hline Eduardo Nobile-Orazio & $\begin{array}{l}\text { 1. Neuromuscular and Neuroimmunology Unit, IRCCS Humanitas Research Hospital, } \\
\text { Rozzano, Italy } \\
\text { 2. Department of Medical Biotechnology and Translational Medicine, Milan } \\
\text { University, Milan, Italy }\end{array}$ \\
\hline Elena Di Sabatino & $\begin{array}{l}\text { Department od Medicine and Surgery, Section of Neurology, University of Perugia, } \\
\text { Perugia, Italy }\end{array}$ \\
\hline Eleonora Cocco & Centro Sclerosi Multipla Ospedale Binaghi Cagliari \\
\hline Elisabetta Signoriello & II Division of Neurology, University of Campania Luigi Vanvitelli \\
\hline Elvira Sbragia & $\begin{array}{l}\text { Department of Neurosciences, Rehabilitation, Ophthalmology, Genetics, Maternal and } \\
\text { Child Health, University of Genova, Italy AND IRCCS Ospedale Policlinico San }\end{array}$ \\
\hline
\end{tabular}


medRxiv preprint doi: https://doi.org/10.1101/2022.01.22.22269630; this version posted January 31, 2022. The copyright holder for this preprint (which was not certified by peer review) is the author/funder, who has granted medRxiv a license to display the preprint in perpetuity.

All rights reserved. No reuse allowed without permission.

\begin{tabular}{|c|c|}
\hline & Martino, Genova, Italy \\
\hline Emanuele Cassano & $\begin{array}{l}\text { Department of Neurosciences, Reproductive Sciences and Odontostomatology, } \\
\text { University of Naples "Federico II", Naples, Italy. }\end{array}$ \\
\hline Enri Nako & Department of Neurology, Regina Montis Regalis Hospital, Mondovì, Italy \\
\hline Fabio Della Cava & Ospedale Civile Imperia \\
\hline Flora Govone & Department of Neurology, Regina Montis Regalis Hospital, Mondovì, Italy \\
\hline Francesca Bianchi & $\begin{array}{l}\text { Department of Clinical and Experimental Medicine, Neurology Unit, University of } \\
\text { Pisa, Italy }\end{array}$ \\
\hline Francesca Caleri & Department of Neurology, MS Center, F. Tappeiner Hospital Meran (BZ), Italy \\
\hline Francesca Ruscica & U.O.C. Neurologia e Centro SM - Fondazione Istituto G. Giglio, Cefalù (Italy) \\
\hline Francesca Vitetta & Neurology Unit, Azienda Ospedaliero-Universitaria of Modena, Modena, Italy \\
\hline Francesco Patti & $\begin{array}{l}\text { Department of Medical and Surgical Sciences and Advanced Technologies, GF } \\
\text { Ingrassia, University of Catania, Catania, Italy. }\end{array}$ \\
\hline Gabriele Siciliano & $\begin{array}{l}\text { Department of Clinical and Experimental Medicine, Neurology Unit, University of } \\
\text { Pisa, Italy }\end{array}$ \\
\hline Gaia Cola & $\begin{array}{l}\text { Department of Systems Medicine, Multiple Sclerosis Clinical and Research Unit, Tor } \\
\text { Vergata } \\
\text { University, Rome, Italy }\end{array}$ \\
\hline Giacomo Lus & II Division of Neurology, University of Campania Luigi Vanvitelli \\
\hline Gianmarco Abbadessa & $\begin{array}{l}\text { Dipartimento di Scienze Mediche e Chirurgiche avanzate, Universit ̀̀ della Campania } \\
\text { Luigi Vanvitelli, Naples-Italy }\end{array}$ \\
\hline Gianmarco Bellucci & $\begin{array}{l}\text { Department of Neuroscience, Mental Health and Sensory Organs } \\
\text { Sapienza University, S. Andrea Hospital, Rome }\end{array}$ \\
\hline Girolama Alessandra Marfia & $\begin{array}{l}\text { Department of Systems Medicine, Multiple Sclerosis Clinical and Research Unit, Tor } \\
\text { Vergata } \\
\text { University, Rome, Italy }\end{array}$ \\
\hline Giuditta Ilaria Scarano & Department of Psychology, F. Tappeiner Hospital Meran (BZ), Italy \\
\hline Giuseppe Liberatore & $\begin{array}{l}\text { Neuromuscular and Neuroimmunology Unit, IRCCS Humanitas Research Hospital, } \\
\text { Rozzano, Italy }\end{array}$ \\
\hline Giuseppina Miele & $\begin{array}{l}\text { Dipartimento di Scienze Mediche e Chirurgiche avanzate, Universit ̀̀ della Campania } \\
\text { Luigi Vanvitelli, Naples-Italy }\end{array}$ \\
\hline Graziella Callari & U.O.C. Neurologia e Centro SM - Fondazione Istituto G. Giglio, Cefalù (Italy) \\
\hline Guido Urbano & Dipartimento di Neuroscienze "Rita Levi Montalcini, Università di Torino \\
\hline Irene Schiavetti & Department of Health Sciences, Section of Biostatistics, University of Genova, Italy \\
\hline Jessica Frau & Centro Sclerosi Multipla Ospedale Binaghi Cagliari \\
\hline Leonardo Malimpensa & Department of Human Neuroscience, Sapienza, University of Rome, Italy \\
\hline Lia Allegorico & Nola Hospital "Santa Maria della Pietà", ASL Napoli 3 Sud, Nola (Na) Italy \\
\hline Livia Pasquali & $\begin{array}{l}\text { Department of Clinical and Experimental Medicine, Neurology Unit, University of } \\
\text { Pisa, Italy }\end{array}$ \\
\hline
\end{tabular}


medRxiv preprint doi: https://doi.org/10.1101/2022.01.22.22269630; this version posted January 31, 2022. The copyright holder for this preprint (which was not certified by peer review) is the author/funder, who has granted medRxiv a license to display the preprint in perpetuity.

All rights reserved. No reuse allowed without permission.

\begin{tabular}{|c|c|}
\hline Lorena Lorefice & Centro Sclerosi Multipla Ospedale Binaghi Cagliari \\
\hline Lorenzo Gaetani & $\begin{array}{l}\text { Department of Medicine and Surgery, Section of Neurology, University of Perugia, } \\
\text { Perugia, Italy }\end{array}$ \\
\hline Lucia Ruggiero & $\begin{array}{l}\text { Department of Neurosciences, Reproductive Sciences and Odontostomatology, } \\
\text { University of Naples "Federico II", Naples, Italy }\end{array}$ \\
\hline Marco Salvetti & $\begin{array}{l}\text { Department of Neuroscience, Mental Health and Sensory Organs. Sapienza University, } \\
\text { S. Andrea Hospital, Rome }\end{array}$ \\
\hline Marco Vercellino & $\begin{array}{l}\text { Multiple Sclerosis Center and 1st Division of Neurology, Department of Neuroscience, } \\
\text { City of Health and Science University Hospital of Turin, Italy }\end{array}$ \\
\hline Maria Chiara Buscarinu & $\begin{array}{l}\text { Department of Neuroscience, Mental Health and Sensory Organs } \\
\text { Sapienza University, S. Andrea Hospital, Rome }\end{array}$ \\
\hline Maria Francesca Creta & $\begin{array}{l}\text { 1. Neuromuscular and Neuroimmunology Unit, IRCCS Humanitas Research Hospital, } \\
\text { Rozzano, Italy } \\
\text { 2. Department of Medical Biotechnology and Translational Medicine, Milan } \\
\text { University, Milan, Italy }\end{array}$ \\
\hline Maria Laura Stromillo & Clinica Neurologica e Malattie Neurometaboliche, Università degli Studi di Siena \\
\hline Maria Pia Sormani & $\begin{array}{l}\text { 1- Department of Health Sciences, Section of Biostatistics, University of Genova, Italy } \\
\text { 2- IRCCS Ospedale Policlinico San Martino, Genova, Italy }\end{array}$ \\
\hline Maria Rosaria Pennacchio & $\begin{array}{l}\text { Multiple Sclerosis Center, Aversa Hospital "San Giuseppe Moscati", ASL Caserta, } \\
\text { Aversa (Ce) Italy }\end{array}$ \\
\hline Maria Teresa Ferrò & $\begin{array}{l}\text { Neuroimmunology, Center for Multiple Sclerosis, Cardiocerebrovascular Department, } \\
\text { Neurological Unit, ASST Crema }\end{array}$ \\
\hline Maria Teresa Rilla & Ospedale Civile Imperia \\
\hline Marinella Clerico & Dipartimento di Scienze Cliniche e Biologiche, Università di Torino \\
\hline Massimiliano Di Filippo & $\begin{array}{l}\text { Department of Medicine and Surgery, Section of Neurology, University of Perugia, } \\
\text { Perugia, Italy }\end{array}$ \\
\hline Matteo Scialabba & U.O.C. Neurologia e Centro SM - Fondazione Istituto G. Giglio, Cefalù (Italy) \\
\hline Mauro Zaffaroni & UOC Centro Sclerosi Multipla, ASST Valle-Olona, PO di Gallarate (VA) \\
\hline Monica Ulivelli & Department of Medical Sciences, Surgery and Neurosciences, University of Siena \\
\hline Nicola De Stefano & Clinica Neurologica e Malattie Neurometaboliche, Università degli Studi di Siena \\
\hline Paola Cavalla & $\begin{array}{l}\text { Multiple Sclerosis Center and 1st Division of Neurology, Department of Neuroscience, } \\
\text { City of Health and Science University Hospital of Turin, Italy }\end{array}$ \\
\hline Paola De Mitri & Guglielmo da Saliceto Hospital, Piacenza \\
\hline Paolo Immovilli & Guglielmo da Saliceto Hospital, Piacenza \\
\hline Patrizia Sola & Neurology Unit, Azienda Ospedaliero-Universitaria of Modena, Modena, Italy \\
\hline Pietro Annovazzi & UOC Centro Sclerosi Multipla, ASST Valle-Olona, PO di Gallarate (VA) \\
\hline Raffaele Nardone & $\begin{array}{l}\text { 1. Paracelsus Medical University, Department of Neurology, Salzburg-AU } \\
\text { 2. Department of Neurology, F. Tappeiner Hospital Meran (BZ), Italy }\end{array}$ \\
\hline
\end{tabular}


medRxiv preprint doi: https://doi.org/10.1101/2022.01.22.22269630; this version posted January 31, 2022. The copyright holder for this preprint (which was not certified by peer review) is the author/funder, who has granted medRxiv a license to display the preprint in perpetuity.

All rights reserved. No reuse allowed without permission.

\begin{tabular}{|l|l|}
\hline Renato Docimo & $\begin{array}{l}\text { Multiple Sclerosis Center, Aversa Hospital "San Giuseppe Moscati", ASL Caserta, } \\
\text { Aversa (Ce) Italy }\end{array}$ \\
\hline Roberta Lanzillo & Federico II university of Naples \\
\hline Rosa Iodice & $\begin{array}{l}\text { Department of Neurosciences, Reproductive Sciences and Odontostomatology, } \\
\text { University of Naples "Federico II", Naples, Italy }\end{array}$ \\
\hline Rosanna Missione & II Division of Neurology, University of Campania Luigi Vanvitelli \\
\hline Sarah Rasia & Centro Sclerosi Multipla ASST Spedali Civili di Brescia \\
\hline Sebastiano Arena & $\begin{array}{l}\text { Department of Medical and Surgical Sciences and Advanced Technologies, GF } \\
\text { Ingrassia, University of Catania, Catania, Italy. }\end{array}$ \\
\hline Simona Bonavita & $\begin{array}{l}\text { Dipartimento di Scienze Mediche e Chirurgiche avanzate, UniversitÀ della Campania } \\
\text { Luigi Vanvitelli, Naples-Italy }\end{array}$ \\
\hline Simona Rolla & Dipartimento di Scienze Cliniche e Biologiche, Università di Torino \\
\hline Vincenzo Brescia Morra & Federico II University of Naples \\
\hline Viola Baione & Department of Human Neuroscience, Sapienza, University of Rome, Italy. \\
\hline
\end{tabular}




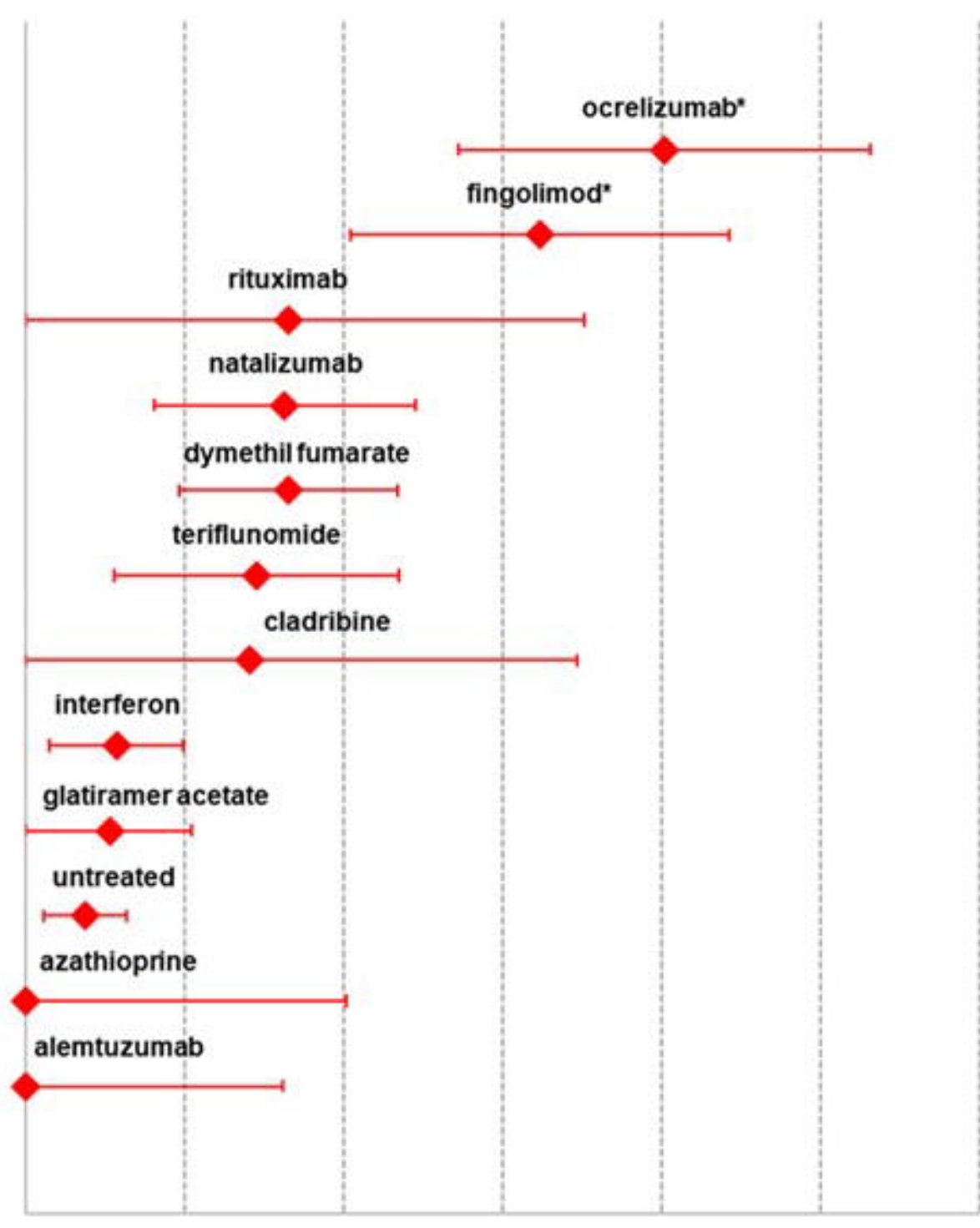

A
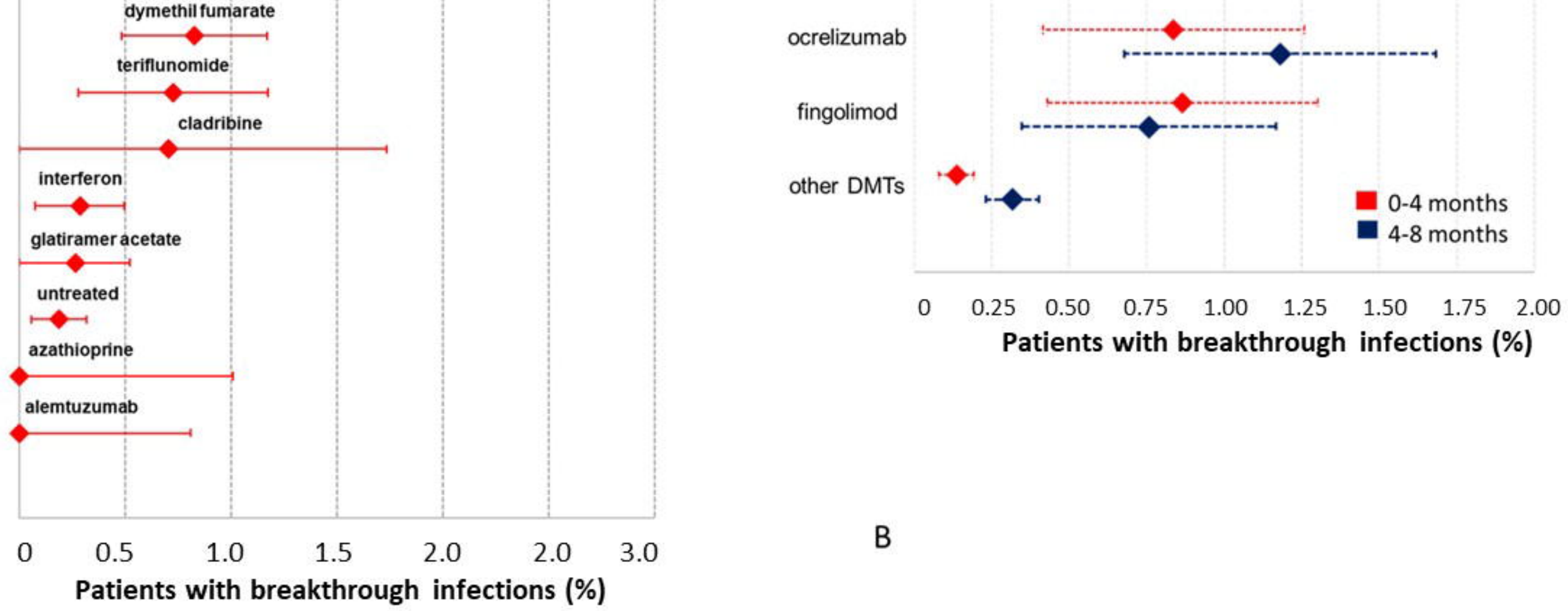

*Ocrelizumab and fingolimod had a percentage of breakthrough infections that is significantly higher (p<0.001) than the percentage in all the other DMT groups. 